\title{
KARAKTERISTIK EKOLOGI DAN SOSIAL EKONOMI LANSKAP HUTAN PADA DAS KRITIS DAN TIDAK KRITIS: STUDI KASUS DI DAS BATURUSA DAN DAS CIDANAU
}

\author{
(Characteristics of Ecology and Social Economics of Forest Landscape \\ in a Critical and a Non Critical Watershed: Case Study Baturusa and \\ Cidanau Watersheds)
}

\author{
Mimi Salminah, Iis Alviya, Virni Budi Arifanti \& Retno Maryani \\ Pusat Penelitian dan Pengembangan Perubahan Iklim dan Kebijakan \\ Jl. Gunung Batu No.5 Bogor, 16610, Indonesia \\ e-mail: mimiaruman@yahoo.com.sg
}

Diterima 3 Maret 2014, direvisi 22 April 2014, disetujui 1 Mei 2014

\begin{abstract}
Forests play a vital role in both environmental and economic development. They maintain not only ecological sustainability, but also provide economic resources such as wood and non wood products. To create its sustainability, the forest management must be conducted on the basic of landscape characteristics of the forest itself. This research aims to analyze characteristics of ecology and social economics of the forest landscape in a critical and a non critical watershesds. Understanding of the characteristics is crucial to set a policy for a sustainable forest landscape management system. The Baturusa and the Cidanau watersheds were chosen as research locations based on representation of the critical and the non critical watershed areas. The data from 2009 were analyzed by the GIS and the qualitative descriptive methods. The result showed that ecological characteristics of the Cidanau watershed were better than those of the Baturusa watershed. However, the economic characteristics of the Baturusa watershed were better than those of the Cidanau watershed. In addition, both areas have similar condition in social characteristics. The programs that have positive impacts on the forest landscape characteristics are apayment environmental service mechanism and intensive campaign to the community regarding the importance of forest conservation.
\end{abstract}

Keywords: Forest, landscape, social economics, ecology

\begin{abstract}
ABSTRAK
Hutan memiliki peran penting baik dalam pembangunan lingkungan dan pembangunan ekonomi. Untuk mewujudkan kelestarian tersebut, sistem pengelolaan hutan harus memperhatikan karakteristik lanskap hutan itu sendiri. Penelitian ini bertujuan untuk menganalisis karakteristik ekologi dan sosial ekonomi DAS kritis dan tidak kritis. Pengetahuan tentang karakteristisk tersebut sangat penting untuk menentukan kebijakan sistem pengelolaan lanskap hutan yang lestari pada suatu wilayah DAS. DAS Cidanau dan DAS Baturusa dipilih sebagai lokasi penelitian dengan pertimbangan keduanya mewakili DAS tidak kritis dan kritis. Data yang dianalisa adalah data tahun 2009 dengan menggunakan metode analisa GIS dan deskriptif kualitatif. Hasil analisis menunjukan bahwa karakteristik ekologi DAS Cidanau lebih baik dibandingkan DAS Baturusa. Sebaliknya, karakteristik ekonomi DAS Baturusa lebih baik dibandingkan DAS Cidanau. Berdasarkan karakteristik sosial, kedua DAS tersebut menunjukan kondisi yang hampir sama. Kegiatan yang dapat memberikan dampak positif terhadap karakteristik lanskap hutan adalah mekanisme jasa lingkungan hulu hilir serta sosialisasi atau penyuluhan tentang pentingnya konservasi hutan kepada masyarakat secara intensif.
\end{abstract}

Kata kunci: Hutan, lanskap. ekologi, sosial, ekonomi

\section{PENDAHULUAN}

Pengelolaan hutan di Indonesia pada dasarnya adalah untuk melestarikan sumber daya hutan dengan mengoptimalkan berbagai fungsinya sehingga mampu mendukung pembangunan nasional. Dalam Rencana Pembangunan Jangka Menengah Nasional (RPJMN) tahun 2010-2014 sektor kehutanan dituntut untuk memiliki peran, baik dalam pembangunan ekonomi maupun pembangunan lingkungan. Dari sisi pembangunan ekonomi, sektor kehutanan diharapkan dapat

Karakteristik Ekologi dan Sosial Ekonomi Lanskap Hutan pada DAS Kritis dan Tidak Kritis: Studi Kasus di ..... (Mimi Salminah et al.) 
memberikan kontribusi dalam penyediaan lapangan kerja, kesempatan berusaha, pendapatan negara, dan perolehan devisa secara nyata. Dari sisi pembangunan lingkungan, sektor kehutanan baik langsung maupun tidak langsung, dituntut untuk dapat memberikan dukungan untuk terselenggaranya pembangunan sektor lain (pertanian dan pangan, pertambangan dan energi, perindustrian, perdagangan, tenaga kerja, keuangan/perbankan, infrastruktur pekerjaan umum, pariwisata, dan lain lain) secara berkelanjutan.

Jennings et al. (2002) menyatakan bahwa hutan memiliki minimal dua peran penting, yaitu (1) untuk memberikan jasa lingkungan dalam situasi kritis (provide basic services of nature in critical situations) seperti perlindungan DAS dan pengontrol erosi, serta (2) untuk memenuhi kebutuhan dasar dari masyarakat lokal (meet basic needs of local communities). Hutan yang telah berperan optimal dalam dua hal tersebut, disebut hutan dengan nilai konservasi yang tinggi atau High Conservation Value Forest (HCVF).

Pengelolaan hutan pada tingkat lanskap dengan mengacu pada prinsip HCVF merupakan upaya untuk menjembatani perbedaan kepentingan terhadap lahan yang saling berseberangan. Konsep manajemen lanskap mengintegrasikan proses sosial ekonomi dan ekologi pada tingkat tapak untuk menjaga keseimbangan antara kelestarian lingkungan dan pemenuhan kebutuhan manusia.

Forman dan Godron (1986) mendefinisikan lanskap sebagai area lahan heterogen yang terdiri dari sekelompok cluster interaksi ekosistemekosistem yang berulang pada bentuk yang sama pada setiap bagian. Sedangkan lanskap hutan didefinisikan sebagai bentang alam yang didominasi oleh adanya hutan yang wilayahnya meliputi daerah hulu hingga bagian hilir suatu Daerah Aliran Sungai (DAS) (Maryani et al. 2010). Dengan demikian, DAS menjadi unit analisis perencanaan serta pengelolaan lanskap hutan secara holistik.

Daerah Aliran Sungai (DAS) adalah suatu wilayah daratan yang merupakan kesatuan ekosistem dengan sungai dan anak-anak sungainya yang dibatasi oleh topografi yang berfungsi menampung air yang berasal dari curah hujan dan sumber air lainnya untuk dialirkan melalui sungai utama yang bermuara di laut atau danau secara alami (Asdak, 2010). Secara biogeofisik DAS bagian hulu merupakan daerah konservasi, kerapatan drainase lebih tinggi, kemiringan lebih besar (di atas $15 \%$ ), bukan merupakan daerah banjir, pengaturan pemakaian air ditentukan oleh pola drainase, dan jenis vegetasi pada umumnya merupakan tegakan hutan. DAS bagian hilir merupakan daerah pemanfaatan, kerapatan drainase lebih kecil, kelerengan rendah (dibawah 8\%), pada beberapa tempat merupakan daerah banjir, pengaturan pemakaian air ditentukan oleh bangunan irigasi, dan jenis vegetasi didominasi oleh tanaman pertanian kecuali daerah estuaria yang didominasi hutan bakau/gambut. DAS bagian tengah merupakan daerah transisi dari kedua karakteristik biogeofisik yang berbeda tersebut (Asdak, 2010).

Rencana Pembangunan Jangka Menengah (RPJM) Kementerian Kehutanan tahun 2010 2014 menyebutkan sebanyak 108 DAS dikategorikan dalam kondisi kritis. Tingkat kekritisan tersebut ditunjukkan oleh menurunnya vegetasi lahan permanen serta meluasnya lahan kritis, yang berakibat pada menurunnya kemampuan DAS dalam menyimpan air.

Karakteristik lanskap hutan di DAS kritis dan non kritis penting dikaji untuk menentukan sistem perencanaan dan pengelolaan lanskap hutan yang berkelanjutan. Penggolongan DAS kritis dan non kritis saat ini masih didasarkan hanya pada karakteristik ekologi. DAS kritis ditandai dengan menurunnya kemampuan DAS dalam menyimpan air, selanjutnya berdampak pada berkurangnya debit air, terjadinya banjir, longsor pada musim hujan dan kekeringan pada musim kemarau (Departemen Kehutanan, 2009). Sedangkan DAS normal atau tidak kritis didefinisikan melalui beberapa indikator, yaitu koefisien air larian berfluktuasi normal, angka coeficient varians (CV) debit aliran lebih kecil dari 10\%, angka koefisien regim sungai normal, tidak banyak terjadi perubahan koefisien arah pada kurva kadar lumpur terhadap debit sungai (Q), debit aliran kecil menunjukan kecenderungan meningkat serta tinggi permukaan air tanah tidak berfluktuasi secara mencolok. Sedangkan indikator DAS yang sudah terganggu apabila koefisien air larian cenderung terus naik, angka koefisien varians debit aliran lebih besar dari 10\%, angka koefisien regim sungai terus naik, kurva Cs terhadap Q semakin tajam, debit aliran kecil menunjukan kecenderungan menurun serta tinggi permukaan air tanah berfluktuasi secara ekstrim (Asdak, 2010). Penelitian ini bertujuan untuk menganalisis besarnya perbedaan karakteristik lanskap hutan 
pada DAS kritis dan non kritis tersebut. Parameter karakteristik lanskap hutan yang dianalisis meliputi, (1) kepadatan penduduk, (2) tingkat pendidikan, (3) tingkat pendapatan, (4) tingkat kesejahteraan, (5) tutupan lahan, (6) debit air, dan (7) tingkat pencemaran air.

\section{METODE PENELITIAN}

\section{A. Kerangka Analisis}

Karakter suatu lanskap dipengaruhi oleh proses pemasaran suatu produk (market process), kelembagaan manusia (buman institutions), pengetahuan manusia (knowledge), dan proses ekologi (ecological process) (Lee et al. dalam Naiman 1992). Begitu pula karakteristik lanskap hutan. Turner (1989), Naiman and Decamps (1990) dalam Naiman (1992) menyatakan perubahan tataguna lahan sangat mempengaruhi pola lanskap (landscape pattern) khususnya berbagai proses ekologi, misalnya suksesi tanaman, biodiversitas dan dinamika makanan.

Upaya pengelolaan lanskap hutan yang lestari harus memperhatikan karakteristik ekologi, sosial dan ekonominya. Pada dasarnya ekologi, sosial maupun ekonomi memiliki banyak unsur, tetapi penelitian ini hanya menganalisis beberapa unsur yang dianggap berkaitan erat dengan pengelolaan lanskap hutan. Unsur-unsur karakter sosial ekonomi yang dianalisis adalah kepadatan penduduk, tingkat pendidikan, tingkat pendapatan dan tingkat kesejahteraan. Sedangkan unsur-unsur karakteristik ekologi yang dianalis adalah tutupan lahan, debit air, dan tingkat pencemaran seperti yang terlihat pada Gambar 1 .

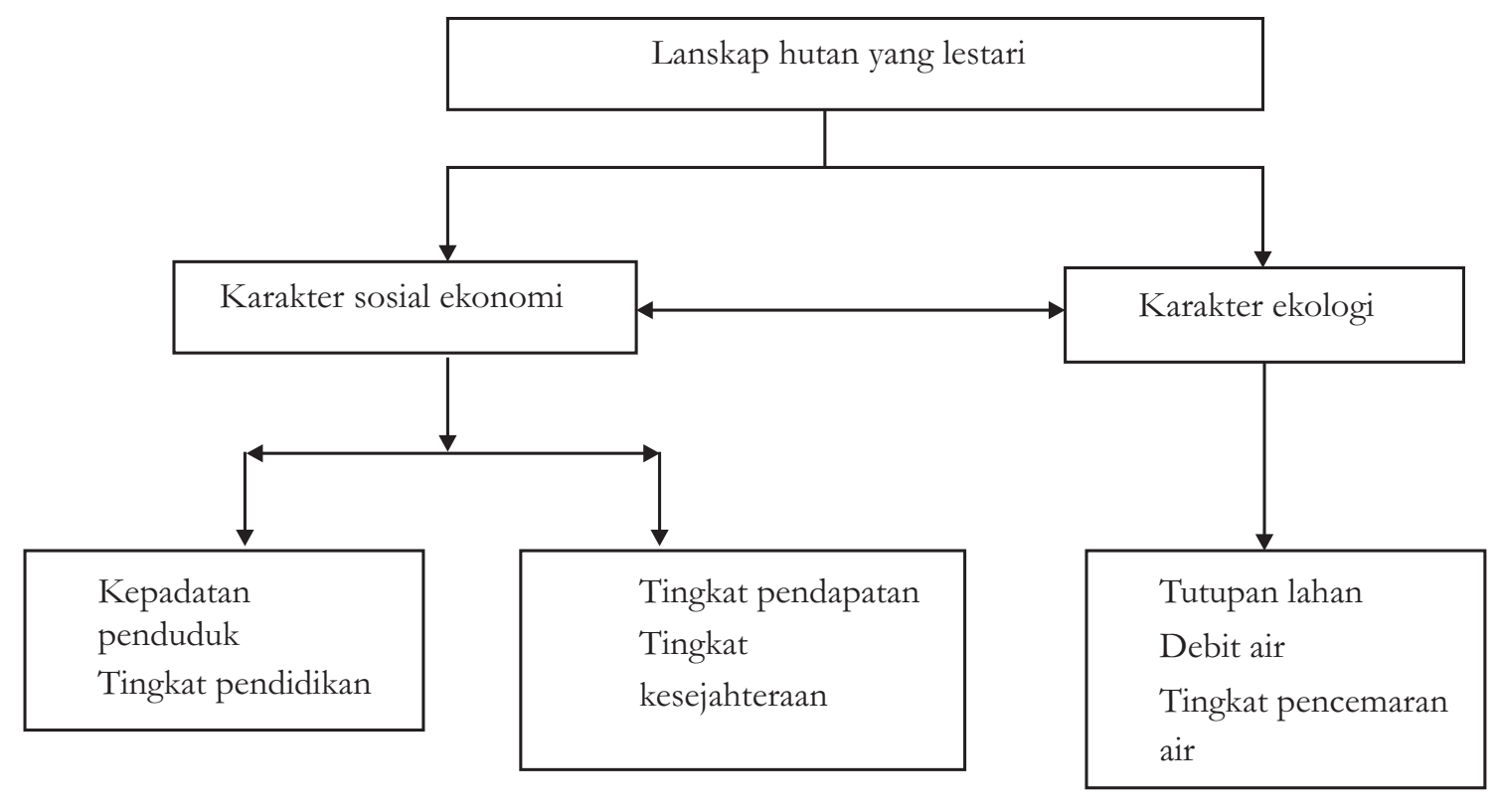

Gambar 1. Kerangka analisis penelitian.

Figure 1. Analysis framework of study.

\section{B. Lokasi dan Waktu Penelitian}

Penelitian dilakukan di DAS Cidanau di Provinsi Banten dan DAS Baturusa di Provinsi Bangka Belitung khususya di wilayah hulu pada bulan April sampai dengan Desember 2011. Penentuan lokasi ini didasarkan pada pertimbangan bahwa DAS Cidanau digolongkan sebagai DAS non-kritis, sedangkan DAS Baturusa merupakan DAS prioritas 1 atau DAS kritis.

\section{Metode Pengumpulan Data}

Data penelitian terdiri atas data primer dan sekunder. Data primer diperoleh dengan teknik pengamatan langsung di lapangan serta dengan menggunakan metode wawancara terhadap kelompok tani, tokoh masyarakat dan stakeholders yang terlibat dalam pengelolaan DAS Cidanau dan Baturusa. Data sekunder diperoleh dari berbagai instansi pemerintah terkait. Penggalian 
data dan informasi selain dilakukan melalui tatap muka dengan responden secara langsung, satu persatu, juga dilakukan dengan cara melakukan
FGD. Jenis dan sumber data yang dikumpulkan sebagaimana terinci pada tabel di bawah.

Tabel. 1. Jenis, sumber, dan teknik mengumpulkan data

Table 1. Types, sources, and technique of data collection

\begin{tabular}{|c|c|c|}
\hline $\begin{array}{l}\text { Jenis Data } \\
\text { (Types of Data) }\end{array}$ & $\begin{array}{l}\text { Sumber Data } \\
\text { (Sources of Data) }\end{array}$ & $\begin{array}{l}\text { Teknik Mengumpulkan } \\
\text { (Technique of Data Collection) }\end{array}$ \\
\hline $\begin{array}{l}\text { Primer: } \\
\text { 1. Indikator tingkat kesejahteraan (Kondisi } \\
\text { lantai, dinding dan atap rumah) } \\
\text { 2. Kondisi topografi } \\
\text { 3. Kualitas air } \\
\text { 4. Proses perubahan tataguna hutan }\end{array}$ & $\begin{array}{l}\text { Kondisi di lapangan, } \\
\text { Masyarakat, FKDC*, Balai } \\
\text { Pengelolaan Pengairan - } \\
\text { Dinas PU, Dinas } \\
\text { Kehutanan }\end{array}$ & $\begin{array}{l}\text { Pengamatan langsung } \\
\text { Wawancara, FGD }\end{array}$ \\
\hline $\begin{array}{ll}\text { Sekunder: } \\
\text { 1. } \\
\text { 2. } \text { Debitupan hutan } \\
\text { 3. } \text { Kualitas air } \\
\text { 4. Tingkat pendidikan } \\
\text { 5. } & \text { Tingkat pendapatan } \\
\text { 6. } & \text { Kepadatan penduduk } \\
\text { 7. } & \text { Proses perubahan tataguna hutan }\end{array}$ & $\begin{array}{l}\text { BP DAS, Dinas } \\
\text { Kehutanan, Dinas PU, } \\
\text { BPS, Bappeda }\end{array}$ & Pengumpulan data sekunder \\
\hline
\end{tabular}

Keterangan (Remarks) : * Forum Kelembagaan DAS Cidanau (Cidanau watershed Institution Form)

\section{Analisis Data}

Karakteristik lanskap hutan dianalisis dengan menggunakan dua cara, yaitu : (i) analisa spasial (GIS) untuk mengidentifikasi elemen-elemen lanskap antara lain: luas tutupan lahan, perubahan tutupan lahan, hubungan antara kepadatan penduduk dan tutupan lahan, hubungan antara tingkat pendapatan dan tutupan lahan; serta (ii) analisa dekriptif kualitatif untuk menggambarkan kondisi ekologi dan sosial ekonomi masyarakat DAS yang meliputi kepadatan penduduk, tingkat pendidikan, tingkat pendapatan, dan kesejahteraan. Analisis spasial digunakan juga untuk validasi kondisi sosial ekonomi masyarakat hasil pengamatan di lokasi penelitian melalui teknik pemetaan. Data kedua lokasi kemudian dibandingkan untuk melihat besarnya perbedaan antara karakteristik lanskap hutan di DAS kritis dan tidak kritis.

\section{HASIL DAN PEMBAHASAN}

Lubchenco et al. (1991) mengemukakan bahwa tantangan besar dalam pengelolaan lingkungan adalah bagaimana dapat menjaga keseimbangan antara kebutuhan manusia dengan kelestarian lingkungan. Dengan demikian sosial, ekonomi, dan ekologi merupakan sebuah interaksi yang kompleks dan saling mempengaruhi. Hal tersebut sesuai dengan kondisi lapangan baik pada DAS Cidanau maupun DAS Baturusa. Selain permasalahan ekologi, dinamika permasalahan sosial dan ekonomi juga sangat komplek pada kedua DAS tersebut, sehingga diperlukan kriteria dan indikator untuk menilai suatu DAS. Hal ini berdasarkan bahwa sebagai satu kesatuan tata air, DAS sangat dipengaruhi oleh kondisi bagian hulu khususnya kondisi biofisik daerah tangkapan dan resapan air yang seringkali rawan terhadap ancaman gangguan manusia. Kondisi tersebut mencerminkan bahwa kelestarian DAS ditentukan oleh pola perilaku, keadaan sosial ekonomi dan tingkat pengelolaan yang sangat erat kaitannya dengan pengaturan kelembagaan.

Kriteria ekologi yang digunakan dalam penelitian ini adalah tutupan lahan, debit air dan tingkat pencemaran air. Kriteria sosial dan ekonomi yang digunakan adalah kepadatan penduduk, tingkat pendidikan, tingkat pendapatan dan kesejahteraan masyarakat. 


\section{A. Karakteristik Ekologis}

\section{Tutupan Hutan}

Berdasarkan analisis GIS, pada tahun 2009 DAS Cidanau memiliki tutupan hutan seluas $7.587,71$ ha atau $32,83 \%$ dari luas DAS yang mencapai 22.455,604 ha (Gambar 2). Sementara itu, luas tutupan hutan di DAS Cibarusa pada tahun yang sama hanya sekitar $2.165,83$ ha atau 3,18\% dari total luas DAS 67.993,76 ha. Tutupan hutan DAS Cidanau terdiri dari hutan lahan kering sekunder (1567,50 ha), hutan tanaman (4281,03 ha), serta perkebunan (1522,75 ha). Perkebunan di DAS Cidanau pada umumnya merupakan kebun campuran antara tanaman hutan yang bersifat cepat tumbuh (fast growing) dan tanaman serba guna seperti rambutan, durian dan melinjo yang dicampur dengan tanaman semusim seperti pisang, jahe dan umbi-umbian sebagai tanaman bawahnya. Dengan kondisi seperti itu, maka tutupan perkebunan dimasukan kedalam tutupan hutan. Luasan tutupan hutan DAS Cidanau sedikit lebih besar $(32,83 \%)$ dibandingkan luas tutupan hutan yang diwajibkan dalam UU 41/1999 tentang kehutanan yang hanya mewajibkan 30\% dari luasan DAS/ wilayah. Namun demikian dengan luasan tersebut, DAS Cidanau memiliki tutupan hutan sepuluh kali lipat dibandingkan DAS Cibarusa.

Berdasarkan kondisi topografinya, DAS Cidanau memiliki topografi yang didominasi oleh pegunungan di sebelah Utara - Barat dan dataran rendah di belahan Selatan dan Timur. Bagian hulu DAS Cidanau merupakan kawasan cagar biosfer Rawa Danau seluas 20.120 ha yang merupakan daerah tangkapan air (catchment area). Selain cagar biosfer, daerah hulu DAS didominasi oleh hutan campuran milik masyarakat. Kondisi topografi yang bergunung-gunung menyebabkan akses masyarakat untuk mencapai areal hutan pun sulit. Kondisi tersebut juga menyebabkan areal hutan sangat sulit untuk diolah menjadi areal penggunaan lain seperti pertanian atau pemukiman. Kondisi ini diindikasikan menjadi salah satu faktor penyebab masih terjaganya areal hutan di DAS Cidanau. Wilayah DAS Cidanau ini mencakup Kecamatan Mandalawangi Kabupaten Pandeglang dan Kecamatan Ciomas, Padarincang serta sebagian Kecamatan Mancak Kabupaten Serang sebagai wilayah hulu. Wilayah tengah dan hilir meliputi Kecamatan Pabuaran dan Kecamatan Cinangka Kabupaten Serang.

Berbeda dengan kondisi DAS Cidanau, kondisi topografi wilayah sekitar DAS Baturusa secara umum adalah dataran rendah yang berawa-rawa dan sebagian kecil merupakan bukit-bukit kecil yang ketinggiannya berkisar antara 0 - $40 \mathrm{mdpl}$, khususnya di bagian utara sungai tersebut (Gambar 3). Pada bagian hulu terdapat hutan dan belukar. Selain itu, di wilayah hulu DAS terdapat juga wilayah pemukiman penduduk. Pada bagian tengah sampai hilir dicirikan dengan hutan air payau berupa mangrove (terdapat sekitar 40 persen bakau, 50 persen Nipah, selebihnya sekitar 10 persen api-api dan sejenisnya). DAS Baturusa meliputi Kabupaten Bangka pada bagian hulu (Kecamatan Bakam dan Kecamatan Merawang), Kabuaten Bangka Tengah di bagian tengah, serta Kabupaten Pangkal Pinang pada bagian hilir.

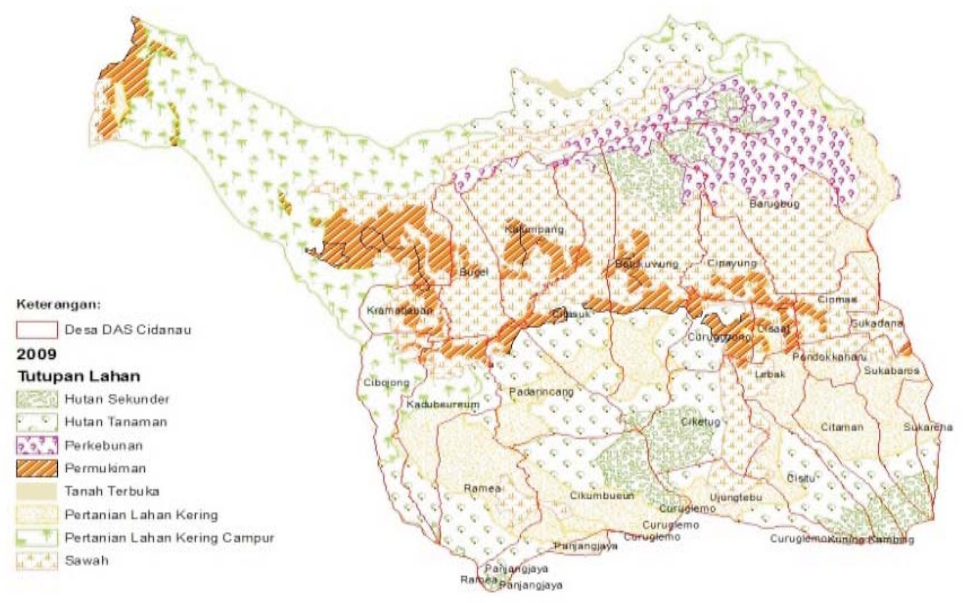

Gambar 2. Kondisi tutupan lahan DAS Cidanau tahun 2009.

Figure 2. Forest Cover at Cidanau Watershed in 2009. 


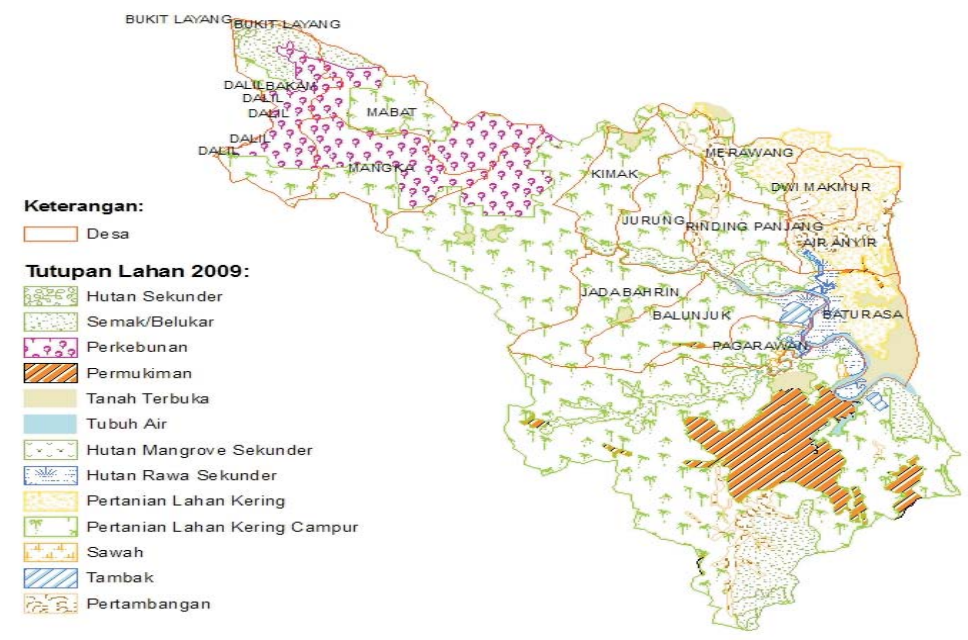

Gambar 3. Tutupan lahan DAS Baturusa tahun 2009

Figure 3. Forest Cover at Baturusa Watershed in 2009

Selain kondisi topografi, faktor yang berpengaruh sehingga luas tutupan hutan di DAS Cidanau terjaga adalah telah dibangun dan dikembangkannya model hubungan hulu-hilir dengan mekanisme transaksi jasa lingkungan (payment for environtmental services). Proses implementasi konsep hubungan hulu-hilir dengan mekanisme transaksi jasa lingkungan di DAS Cidanau difasilitasi oleh Forum Komunikasi DAS Cidanau (FKDC). Forum ini dibangun dan dikembangkan oleh para pihak yang terlibat dalam pengelolaan dan pemanfaatan DAS Cidanau. Tujuan dibentuknya forum ini adalah untuk menjaga kuantitas, kualitas dan keberlanjutan ketersediaan air baku di Sungai Cidanau. Sungai Cidanau berfungsi untuk memenuhi kebutuhan air bersih masyarakat dan industri yang berada di kota Cilegon dan sekitarnya, sekaligus untuk mendukung keberlanjutan proses pembangunan di wilayah barat Provinsi Banten.

Sungai Cidanau merupakan satu-satunya sungai besar yang dapat digunakan untuk memenuhi kebutuhan air bersih bagi industri dan domestik di wilayah hilir khususnya Kota Cilegon. Air Sungai Cidanau dimanfaatkan oleh PT KTI (Krakatau Tirta Industri) yang merupakan anak perusahaan Krakatau Steel yang berperan sebagai penyedia air bersih untuk Kota Cilegon dan sekitarnya. Pada tahun 2007, PT KTI telah memanfaatkan aliran sungai Cidanau hingga 1200 lt/detik. Kondisi ini selaras dengan pandangan Bennet (1976) yang menyatakan bahwa sebagai organisme yang kompleks dengan kemampuan budaya untuk memodifikasi lingkungan yang tinggi, manusia baik langsung maupun tidak langsung, dapat mempengaruhi hampir seluruh ekosistem daratan maupun perairan. Sebaliknya proses ekologi suatu ekosistem dapat mempengaruhi kondisi sosial ekonomi manusia, seperti kemampuan produksi barang dan jasa.

Berdasarkan hasil wawancara dengan FKDC, telah terjalin kesepakatan antara pihak KTI sebagai pengguna dengan masyarakat wilayah hulu DAS Cidanau sebagai pengelola hutan, dan difasilitasi oleh FKDC, pada tahun 2005 masyarakat membuat kesepakatan dengan PT KTI untuk melestarikan hutan di hulu DAS Cidanau. PT KTI memberikan insentif sebesar Rp 1,2 juta/ha/th dengan syarat masyarakat harus mengkonservasi hutan seluas 25 ha selama periode lima tahun. Tanaman yang ditanam adalah tanaman hutan serbaguna yang dicampur dengan tanaman semusim. Tanaman hutan tidak boleh ditebang selama lima tahun, tetapi dapat dimanfaatkan buah atau rantingnya. Nilai kontrak meningkat menjadi Rp 1,7 juta/ha/th pada kontrak kedua dengan areal hutan yang dikonservasi seluas 50 ha.

Dengan adanya insentif untuk masyarakat di hulu DAS dari pengguna air di wilayah hilir, memacu masyarakat untuk terus menjaga kelestarian hutannya. Mereka pada umumnya merasa senang mendapatkan tambahan penghasilan dari lahan hutannya selain mereka juga dapat menikmati penghasilan dari hasil tanaman hutannya seperti durian, petai, melinjo dan pisang. Hal ini selaras dengan pandangan Lee et al. dalam 
Naiman (1992) yang menyatakan bahwa karakteristik suatu lanskap dipengaruhi oleh proses pemasaran suatu produk, kelembagaan manusia, pengetahuan manusia dan proses ekologi.

Sementara itu, pada DAS Cibarusa belum terdapat mekanisme insentif jasa lingkungan terutama terkait dengan pemanfaatan air dan pengelolaan hutan. Kondisi alam Kepulauan Bangka Belitung secara umum dilimpahi kandungan timah yang melimpah. Sekitar $40-50 \%$ timah yang beredar di pasar dunia berasal dari pulau ini. Pertambangan timah di Kabupaten Bangka banyak terdapat di areal hutan. Luas pertambangan di areal hutan mencapai 100.544 ha yang sebagian besar $(79,83 \%)$ berada di hutan produksi, dan 20,61\% berada di kawasan lindung. Sedangkan areal bekas tambang di Kabupaten Pangkalpinang telah dikonversi menjadi perkantoran, perumahan hutan kota, serta masih dalam kondisi areal terbuka (BPDAS Baturusa Cerucuk, 2010).

Selain telah berdirinya dua perusahaan timah besar yang legal yaitu PT Timah Tbk dan PT Koba Tin, pada wilayah DAS ini juga terjadi penambangan illegal yang disebut PETI (penambangan tanpa ijin) oleh masyarakat. PETI ini menjadi sumber mata pencaharian utama bagi sebagian besar masyarakat. Pendapatan yang diperoleh dari hasil menambang digunakan oleh masyarakat untuk mengelola kebun seperti karet dan lada sebagai sumber mata pencaharian yang lain. Tingginya pendapatan yang dihasilkan dari tambang dan perkebunan merupakan daya tarik bagi masyarakat untuk terus menggelutinya walaupun mereka tahu bahwa kegiatan PETI merusak kondisi hutan. Hal ini menjadi kendala sulitnya mekanisme jasa lingkungan diimplementasikan sehingga berdampak terhadap kondisi hutan yang semakin rusak.

\section{Debit Air}

Debit aliran adalah laju air (dalam bentuk volume air) yang melewati suatu penampang melintang sungai per satuan waktu. Dalam satuan sistem internasional (SI) debit dinyatakan dalam satuan meter kubik per detik $\left(\mathrm{m}^{3} / \mathrm{dtk}\right)$. Debit air dalam suatu aliran DAS berasal dari air larian (surface run off) serta aliran air bawah permukaan (subsurface flow).

Perbedaan debit air antara DAS Cidanau dan DAS Baturusa sangat ekstrem. Hal ini berkaitan erat dengan kondisi tutupan lahannya. Dengan tutupan hutan yang mencapai 32,83\%, DAS
Cidanau memiliki debit air sebesar 7,08 $\mathrm{m}^{3} / \mathrm{dtk}$. Sedangkan DAS Baturusa dengan tutupan hutan yang hanya mencapai 3,18\% memiliki debit air sebesar 0,182 ml/s. Keterkaitan luas tutupan hutan dengan kondisi debit air juga ditunjukan dengan penurunan debit air di DAS Cidanau dari tahun 2006 yang mencapai $7,73 \mathrm{~m}^{3} / \mathrm{dtk}$ menjadi 7,08 $\mathrm{m}^{3} /$ dtk pada tahun 2009 akibat konversi hutan menjadi lahan pertanian seluas 179,665 ha. Hal ini selaras dengan pandangan Turner (1989), Naiman dan Decamps (1990) yang menyatakan bahwa perubahan tataguna lahan sangat mempengaruhi pola lanskap (lanscape pattern) khususnya hidrologi dan berbagai proses ekologi, seperti suksesi tanaman, biodiversitas, dan dinamika makanan.

Perubahan debit air dalam suatu aliran DAS dipengaruhi secara langsung oleh perubahan lanskap hutan khususnya perubahan tutupan lahan maupun jenis vegetasinya. Luas dan jenis vegetasi tutupan lahan berperan : (1) sebagai pengurang atau pembuang cadangan air di bumi melalui proses evapotranspirasi dan pemakaian air konsumtif untuk pembentukan jaringan tubuh vegetasi; (2) menambah titik-titik air di atmosfer; (3) sebagai penghalang untuk sampainya air di bumi melalui proses intersepsi; serta (4) sebagai pengurang atau peredam energi kinetik aliran air melalui tahanan permukaan dari bagian batang di permukaan, dan melalui tahanan aliran air permukaan karena adanya serasah di permukaan. Selain itu hutan juga berperan untuk meningkatkan infiltrasi air. Dengan kata lain hutan melakukan fungsi hidrologis sebagai penyerap, penyimpan, penghasil dan pendistribusi air (Asdak, 2010).

\section{Tingkat Pencemaran Air}

Tingkat pencemaran khususnya air merupakan indikator penting dalam kelestarian pengelolaan lanskap hutan di suatu DAS. Perubahan dan pemanfaatan tataguna lahan di luar sektor kehutanan seperti untuk pertanian, pertambangan, industri atau perumahan akan berpengaruh terhadap kualitas air. Davis dan Cornwell (1991) dalam Hefni (2003) mengemukakan beberapa jenis pencemar dan sumbernya seperti yang terlihat pada Tabel 2 berikut ini.

Banyaknya industri, daerah pertambangan dan pertanian yang menggunakan bahan kimia, selain menurunkan daya dukung lahan, juga memicu penurunan kualitas air. Hal ini mengakibatkan kualitas air tersebut tidak memenuhi kriteria untuk 
dimanfaatkan, meskipun secara kuantitas ketersediaan air mencukupi untuk memenuhi kebutuhan. Hammer dan Mac Kichan, 1981 dalam Asdak (2010) menetapkan standar kualitas air permukaan sebagaimana Tabel 3 .

Kualitas air sebagai salah satu indikator keberhasilan pengelolaan DAS didasarkan pada Peraturan Pemerintah Nomor 82 tahun 2001 tentang Pengelolaan Kualitas Air dan Pengendalian Pencemaran. Pengelolaan DAS harus dapat menjamin agar kualitas air tetap dalam kondisi alamiahnya dan sesuai dengan baku mutu air. Baku mutu air adalah ukuran batas atau kadar makhluk hidup, zat, energi, atau komponen yang ada atau harus ada dan atau unsur pencemar yang ditoleransi keberadaannya di dalam air (PP No 82 tahun 2011 pasal 1 ayat 19). Jika merujuk pada peraturan tersebut khususnya pasal 14, maka kualitas air sungai DAS Cidanau yang masih layak minum termasuk kategori memenuhi baku mutu air dan telah dimanfaatkan oleh PDAM Serang untuk memenuhi kebutuhan air minum Kabupaten Serang serta oleh PT KTI untuk memenuhi kebutuhan industri Krakatau Steel (Bappeda, 2008). Sementara itu, kualitas air sungai DAS Baturusa yang sudah tercemar termasuk kategori tidak memenuhi baku mutu air pencemaran air di daerah hulu hingga hilir DAS akibat aktivitas pertambangan.

Tabel 2. Jenis dan sumber pencemaran air

Table 2. Types and Sources of Water Polution

\begin{tabular}{|c|c|c|c|c|}
\hline \multirow[b]{2}{*}{$\begin{array}{l}\text { Jenis Pencemar } \\
\text { (Types of Polution) }\end{array}$} & \multicolumn{2}{|c|}{$\begin{array}{l}\text { Sumber Tertentu } \\
\text { (Point Source) }\end{array}$} & \multicolumn{2}{|c|}{$\begin{array}{l}\text { Sumber Tak Tentu } \\
\text { (Non Point Source) }\end{array}$} \\
\hline & $\begin{array}{c}\text { Limbah } \\
\text { Domestik } \\
\text { (Domestic waste) }\end{array}$ & $\begin{array}{c}\text { Limbah } \\
\text { Industri } \\
\text { (Industry waste) }\end{array}$ & $\begin{array}{c}\text { Limpasan } \\
\text { Daerah } \\
\text { Pertanian } \\
\text { (Farm Runoff) }\end{array}$ & $\begin{array}{c}\text { Limpasan } \\
\text { Daerah } \\
\text { Perkotaan } \\
\text { Urban Runoff) }\end{array}$ \\
\hline $\begin{array}{l}\text { 1. Limbah yang dapat menurunkan } \\
\text { kadar oksigen }\end{array}$ & $\mathrm{X}$ & $\mathrm{X}$ & $\mathrm{X}$ & $\mathrm{X}$ \\
\hline 2. Nutrien & $\mathrm{X}$ & $\mathrm{X}$ & $\mathrm{X}$ & $\mathrm{X}$ \\
\hline 3. Patogen & $\mathrm{X}$ & $\mathrm{X}$ & $\mathrm{X}$ & $\mathrm{X}$ \\
\hline 4. Sedimen & $\mathrm{X}$ & $\mathrm{X}$ & $\mathrm{X}$ & $\mathrm{X}$ \\
\hline 5. Garam-garam & - & $\mathrm{X}$ & $\mathrm{X}$ & $\mathrm{X}$ \\
\hline 6. Logam yang toksin & - & $\mathrm{X}$ & - & $\mathrm{X}$ \\
\hline 7. Bahan organik yang toksin & - & $\mathrm{X}$ & $\mathrm{X}$ & - \\
\hline 8. Pencemaran panas & - & $\mathrm{X}$ & - & - \\
\hline
\end{tabular}

Tabel 3. Standar kualitas air permukaan

Table 3. Quality Standar of Surface Water

\begin{tabular}{|c|c|c|c|c|}
\hline \multirow[b]{2}{*}{$\begin{array}{l}\text { Pemanfaatan Air } \\
\text { (Use of Water) }\end{array}$} & \multicolumn{2}{|c|}{$\begin{array}{c}\mathrm{O} 2 \text { terlarut minimum/O2 } \\
\text { Minimum Dissolved }\end{array}$} & \multirow{2}{*}{$\begin{array}{c}\text { Besarnya partikel yang } \\
\text { diperbolehkan (The } \\
\text { Number of particles } \\
\text { allowed) }\end{array}$} & \multirow{2}{*}{$\begin{array}{c}\text { Besarnya coliform maksimum yang } \\
\text { diperbolehkan (per } 100 \mathrm{ml} \text { ) } \\
\text { (The Maximum Number } \\
\text { of Coliform Allowed) }\end{array}$} \\
\hline & $\begin{array}{l}\text { Terlarut } \\
\text { (Dissolved) } \\
\text { (mg/ltr) }\end{array}$ & $\begin{array}{l}\text { Lainnya } \\
\text { (Others) } \\
\text { (mg/ltr) }\end{array}$ & & \\
\hline $\begin{array}{l}\text { Konsumsi } \\
\text { manusia }\end{array}$ & 4,0 & $500-750$ & $\begin{array}{l}\text { Tidak ada partikel } \\
\text { melayang atau } \\
\text { terdeposit }\end{array}$ & 2000 fecal \\
\hline Rekreasi air & $4-5$ & Tidak ada & Sda & $\begin{array}{l}200 \text { fecal dengan jumlah sampel }(, 10) \\
\text { tidak melebihi } 400 \text { fecal }\end{array}$ \\
\hline $\begin{array}{l}\text { Budidaya } \\
\text { perikanan }\end{array}$ & $4-6$ & Tidak ada & Sda & Rata-rata 1000 fecal \\
\hline Industri & $3-5$ & $750-1500$ & Sda & Umumnya tidak dirinci \\
\hline Pertanian & $3-5 a$ & $\begin{array}{l}750-1500 \\
\text { tergantung } \\
\text { pada iklim }\end{array}$ & Sda & Sda \\
\hline
\end{tabular}




\section{B. Karakteristik Sosial}

\section{Kepadatan Penduduk}

Wagner (2005) menyatakan bahwa untuk menyusun perencanaan pengelolaan DAS yang efektif, tidak hanya didasarkan pada kondisi fisik DAS tersebut, tetapi juga harus berdasarkan informasi kondisi sosial masyarakat. Hal ini ditujukan agar sistem pengelolaan DAS tersebut sesuai dengan kondisi dan kebutuhan masyarakat lokal.

Seperti halnya pada karakteristik ekonomi, pembagian DAS kritis dan non kritis di Indonesia belum memperhatikan karakteristik sosial. Oleh karena itu, sampai saat ini belum disepakati kriteria dan indikator ekonomi dan sosial pada pengelolaan DAS. Permasalahan sosial yang dianalisis pada penelitian ini adalah semakin meningkatnya pertambahan penduduk dari waktu ke waktu. Kepadatan penduduk merupakan faktor yang penting sebagai kriteria dan indikator sosial dalam pengelolaan DAS. Hal ini sesuai dengan pernyataan Paimin et al. (2012) bahwa kepadatan penduduk berpengaruh terhadap kinerja dan kerentanan DAS karena jumlah dan aktivitas penduduk berpengaruh terhadap kelestarian lahan. Semakin tinggi jumlah penduduk semakin besar pula tekanan pada lahan. Wilayah dengan kepadatan penduduk yang tinggi perlu mendapat perhatian yang lebih tinggi karena beresiko tinggi terjadi kerusakan lingkungan akibat pemanfaatan lahan dan air yang lebih besar. Kondisi tersebut menyebabkan permasalahan dalam pengelolaan lanskap hutan kerap kali muncul, karena perubahan dan kondisi penduduk setempat turut berpengaruh dalam perkembangan fisik, perekonomian dan sosial budaya lanskap hutan. Peningkatan jumlah penduduk menyebabkan aktivitas masyarakat banyak menggantungkan hidupnya pada lahan.

Tingkat ketergantungan penduduk terhadap lahan dapat dilihat berdasarkan perbandingan jumlah penduduk yang berdomisili di wilayah tersebut dengan luas wilayah dalam satuan jiwa $/ \mathrm{km}^{2}$ (kepadatan penduduk). Berdasarkan data BPS, ratarata jumlah penduduk desa pada kecamatan Ciomas, Padarincang dan Mandalawangi yang merupakan wilayah hulu DAS Cidanau pada tahun 2009 secara berturut-turut adalah 3.724; 4.754; dan 2.811 jiwa. Adapun rata-rata luas wilayah desa pada kecamatankecamatan tersebut secara berturut-turut adalah
$3,33 \mathrm{~km}^{2} ; 7,41 \mathrm{~km}^{2} ;$ dan $4,148 \mathrm{~km}^{2}$. Dengan demikian, rata-rata tingkat ketergantungan penduduk terhadap lahan pada wilayah hulu DAS Cidanau (Kecamatan Ciomas, Padarincang, dan Mandalawangi) secara berturut-turut adalah 1118,3 jiwa $/ \mathrm{km}^{2} ; 641,6$ jiwa $/ \mathrm{km}^{2}$; dan 677,7 jiwa $/ \mathrm{km}^{2}$. Sedangkan rata-rata keseluruhan tingkat ketergantungan penduduk terhadap lahan di hulu DAS Cidanau adalah 812,5 jiwa $/ \mathrm{km}^{2}$.

Berdasarkan data tersebut, kepadatan penduduk Kecamatan Ciomas dan Mandalawangi sudah melampaui kepadatan penduduk tingkat Kabupaten dimana tingkat kepadatan penduduk Kabupaten Serang adalah 983 jiwa $/ \mathrm{km}^{2}$ dan Kabupaten Pandeglang yaitu 418 jiwa $/ \mathrm{km}^{2}$. Kepadatan penduduk di hulu DAS Cidanau termasuk kategori padat. Hal ini berdasarkan kriteria sosial dalam materi sidik cepat pengelolaan DAS yang mengelompokkan kepadatan penduduk kurang dari kepadatan rata-rata kabupaten maka tergolong rendah, kepadatan penduduk sama dengan kepadatan rata-rata kabupaten maka tergolong sedang, dan kepadatan penduduk yang melebihi kepadatan penduduk rata-rata kabupaten maka tergolong tinggi/padat (Paimin, 2010).

Semakin tinggi kepadatan penduduk suatu wilayah, menyebabkan kebutuhan lahan untuk pemukiman juga semakin tinggi. Tingginya kebutuhan lahan untuk pemukiman, pertanian dan sektor lainnya menyebabkan keberadaan hutan sangat rentan terhadap konversi. Hal ini juga terlihat dari hasil analisis GIS di wilayah hulu DAS Cidanau. Analisis GIS mengindikasikan bahwa desa dengan kepadatan penduduk yang cukup tinggi memiliki areal pemukiman yang tinggi pula. Adapun desa dengan kepadatan penduduk yang rendah umumnya memiliki luasan hutan, perkebunan dan pertanian yang cukup luas.

Kondisi sebaliknya terjadi di hulu DAS Baturusa. Kepadatan penduduk di hulu DAS Baturusa lebih rendah dibandingkan dengan kondisi di hulu DAS Cidanau. Dua kecamatan di Kabupaten Bangka yang merupakan wilayah hulu DAS Baturusa adalah Kecamatan Bakam dan Merawang. Kecamatan Bakam terdiri atas lima desa, sementara Kecamatan Merawang sembilan desa. Luas wilayah dan jumlah penduduk masingmasing desa pada kedua kecamatan tersebut dapat dilihat pada Tabel 4. 


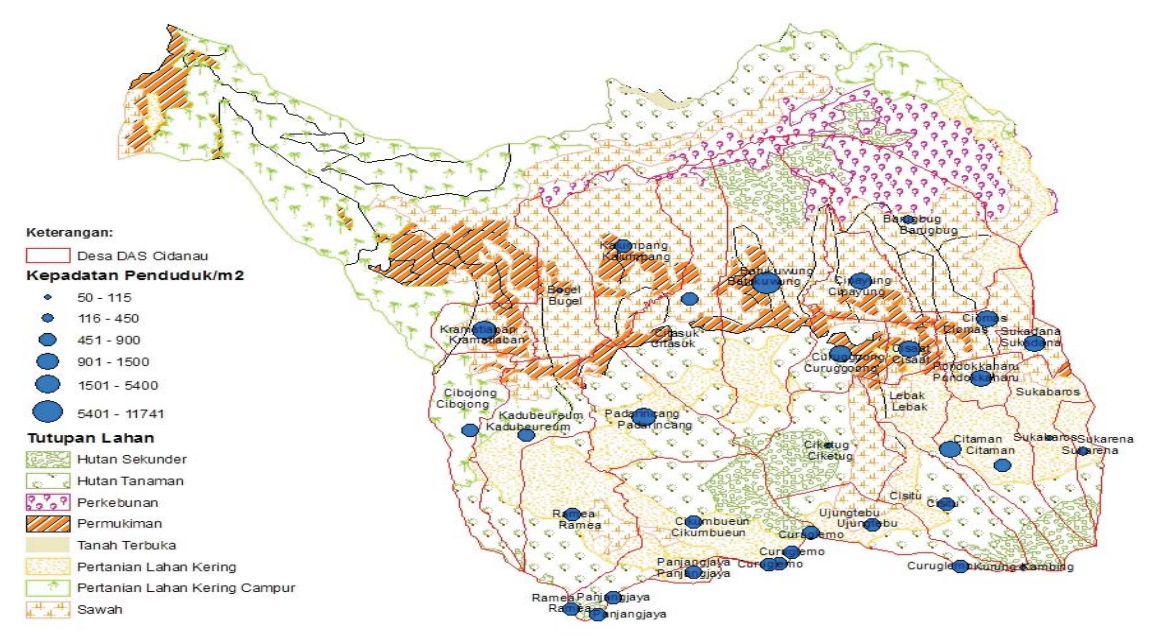

Gambar 4. Sebaran kepadatan penduduk (jiwa $/ \mathrm{km}^{2}$ ) dalam DAS Cidanau.

Figure 4. Distribution of Population Density at Cidanau Watershed.

Tabel 4. Luas wilayah, jumlah penduduk dan kepadatan penduduk di DAS Baturusa

Table 4. Total Area, Population, and Population Density at Baturusa Watershed

\begin{tabular}{|c|c|c|c|c|}
\hline & $\begin{array}{l}\text { Kecamatan/Desa } \\
\text { (Sub-District / Village) }\end{array}$ & $\begin{array}{c}\text { Luas Daerah (Total Area) } \\
\left(\mathrm{km}^{2}\right)\end{array}$ & $\begin{array}{l}\text { Jumlah Penduduk } \\
\text { (Population) } \\
\text { (orang) }\end{array}$ & $\begin{array}{l}\text { Kepadatan Pendududk } \\
\text { Per km² (Population } \\
\text { Density per km²) }\end{array}$ \\
\hline \multicolumn{5}{|c|}{ Kecamatan Bakam } \\
\hline 1 & Desa Dalil & 66,35 & 2.920 & 44 \\
\hline 2 & Desa Mangka & 26,20 & 878 & 34 \\
\hline 3 & Desa Bakam & 24,57 & 1.547 & 63 \\
\hline 4 & Desa Mabat & 100,10 & 1.341 & 13 \\
\hline 5 & Desa Bukit Layang & 252,70 & 3.035 & 12 \\
\hline \multicolumn{2}{|c|}{ Total } & & & 166 \\
\hline \multicolumn{2}{|c|}{ rata-rata } & & & 33 \\
\hline \multicolumn{5}{|c|}{ Kecamatan Merawang } \\
\hline 1 & Desa Kimak & 48,93 & 3.013 & 62 \\
\hline 2 & Desa Merawang & 12,00 & 1.607 & 134 \\
\hline 3 & Desa Baturusa & 10,80 & 4.012 & 371 \\
\hline 4 & Desa Jadha Bahrin & 56,00 & 1.554 & 28 \\
\hline 5 & Desa Balun Ijuk & 12,02 & 3.649 & 304 \\
\hline 6 & Desa Dwi Makmur & 8,55 & 789 & 92 \\
\hline 7 & Desa Air Anyir & 12,90 & 1.698 & 132 \\
\hline 8 & Desa Jurung & 13,30 & 2.282 & 172 \\
\hline 9 & Desa Pagarawan & 11,67 & 4.053 & 347 \\
\hline \multicolumn{2}{|c|}{ Total } & & & 1,641 \\
\hline \multicolumn{2}{|c|}{ Rata-rata } & & & 182 \\
\hline
\end{tabular}


Berdasarkan Tabel 4 terlihat bahwa kepadatan penduduk secara rata-rata untuk desa-desa yang ada di Kecamatan Bakam dan Merawang secara berturut-turut adalah 33 jiwa $/ \mathrm{km}^{2}$ dan 182 jiwa $/ \mathrm{km}^{2}$. Sedangkan rata-rata kepadataan penduduk di hulu DAS Baturusa secara keseluruhan adalah 107,5 jiwa $/ \mathrm{km}^{2}$. Kepadatan penduduk tersebut berada di bawah tingkat kepadatan penduduk Kabupaten Bangka yang mencapai 193 jiwa $/ \mathrm{km}^{2}$. Angka tersebut jauh lebih kecil dibandingkan dengan kepadatan penduduk masyarakat desa di hulu DAS Cidanau dan masuk dalam kategori wilayah berpenduduk jarang/rendah.

Jika dibandingkan antara kepadatan penduduk dengan luas tutupan lahan di kedua DAS tersebut, terlihat bahwa dengan kepadatan penduduk yang lebih tinggi, hulu DAS Cidanau memiliki tutupan hutan yang lebih luas dibandingkan hulu DAS Baturusa. Hal tersebut menunjukkan bahwa mekanisme jasa lingkungan hulu-hilir di DAS Cidanau telah memberikan manfaat penting dalam menjaga kelestarian hutan. Di sisi lain, kasus pada DAS Baturusa nilai ekonomi tambang dan hasil perkebunan memiliki kontribusi lebih tinggi dibandingkan hutan, sehingga penduduk lebih tertarik memanfaatkan lahannya untuk pertambangan dan perkebunan dibandingkan untuk kehutanan.

Selain berpengaruh terhadap kondisi tutupan lahan, tingginya tingkat ketergantungan penduduk terhadap lahan juga berpengaruh terhadap kualitas air dalam sebuah areal DAS. Wagner (2005) menyatakan bahwa DAS dengan lahan pertanian yang luas akan meningkatkan polusi pada sumber air minum.

\section{Pendidikan}

Tingkat pendidikan dianalisis sebagai salah satu karakteristik sosial lanskap hutan dengan pertimbangan bahwa tingkat pendidikan memiliki korelasi dengan perilaku konservasi dalam pengelolaan lanskap hutan. Asumsi yang digunakan adalah bahwa masyarakat dengan pendidikan yang lebih baik akan memiliki kecenderungan perilaku yang menunjukaan kepedulian terhadap pentingnya manfaat konservasi lanskap hutan dalam suatu DAS. Tingkat pendidikan yang baik akan memudahkan dalam pembentukan kesepahaman terhadap masalah pengelolaan DAS antara masyarakat lokal dengan Pemerintah.
Burroughs (1999) menyatakan bahwa masyarakat yang tidak memahami apa yang disampaikan perencana pengelolaan DAS akan mengakibatkan ketidakpedulian dan ketidakaktifan terhadap pengelolaan DAS.

Tingkat pendidikan masyarakat juga sangat berhubungan dengan penerapan inovasi baru karena masyarakat lebih mudah menyerap teknologi baru. Jenjang pendidikan yang dimiliki masyarakat akan meningkatkan keahliannya dan akan berpengaruh terhadap produktivitas sumber daya manusia itu sendiri. Selain itu, Pendidikan juga memiliki hubungan yang terkait dengan kemiskinan, karena menurut data BPS pendidikan sangat berperan dalam mempengaruhi angka kemiskinan. Orang yang berpendidikan lebih baik akan mempunyai peluang yang lebih rendah untuk menjadi miskin.

Menurut data BPS, tercatat di Kecamatan Ciomas jumlah lulusan SD pada tahun 2009 adalah 78,3\%, SLTP 12,5\%, dan SLTA 8,6\%. Sementara di kecamatan Padarincang jumlah lulusan SD $77,6 \%$, SLTP 17,8\% dan SLTA hanya 3,3\%. Lain halnya dengan 5 desa yang masuk dalam wilayah hulu DAS di Kecamatan Mandalawangi, mereka hanya terdiri atas 90,3\% lulusan SD, dan 9,7\% lulusan SLTP, sementara lulusan SLTA adalah nol.

Kondisi pendidikan masyarakat DAS Baturusa tidak jauh berbeda dengan masyarakat DAS Cidanau. Sebanyak hampir 80\% masyarakat DAS Baturusa berpendidikan SD, sekitar 15\% SMP, dan kurang dari 10\% SD. Berdasar tingkat pendidikannya, di Kecamatan Bakam, jumlah penduduk yang memiliki tingkat pendidikan SD adalah 78\%, SLTP 19,6\% dan SLTA 2,3\%, sementara itu di Kecamatan Merawang penduduk dengan latar belakang pendidikan SD adalah 78,3\%, SLTP $11,27 \%$ dan SLTA 10,43\%.

Walaupun tingkat pendidikan masyarakat DAS Cidanau dan DAS Baturusa cenderung sama, yaitu tingkat SD, namun berdasarkan pengamatan di lapangan masyarakat DAS Cidanau memiliki kesadaran konservasi lebih tinggi dibandingkan masyarakat di hulu DAS Baturusa. Masyarakat di hulu DAS Cidanau lebih banyak tersentuh kegiatan sosialisasi dan penyuluhan mengenai pentingnya manfaat keberadaan hutan yang dilakukan oleh FKDC secara intensif. Hal ini sesuai dengan hasil penelitian Rhoads et al. (1999) yang menyatakan bahwa pengelolaan DAS akan efektif jika 
perencana dalam hal ini Pemerintah mengkomunikasikan sistem pengelolaan tersebut kepada masyakarakat lokal, dan masyarakat lokal dilibatkan secara aktif.

Selain itu, adanya mekanisme jasa lingkungan hulu-hilir juga memacu masyarakat di hulu DAS Cidanau untuk terus menjaga kelestarian hutan. Hal ini sesuai dengan hasil penelitian Napier and Forster (1982) yang menyatakan bahwa insentif ekonomi merupakan salah satu faktor penting yang mempengaruhi masyarakat dalam pengelolaan DAS. Berdasarkan hasil wawancara, masyarakat memiliki kepedulian yang tinggi terhadap konservasi hutan semenjak sering terjadinya banjir dan longsor di daerah hulu DAS Cidanau di masa lalu serta sulitnya mengolah areal hutannya menjadi penggunaan lain seperti areal pertanian atau pemukiman.

\section{Karakteristik Ekonomi}

Suparmoko (2008) menyatakan bahwa terdapat hubungan yang positif antara kuantitas barang sumber daya dan pertumbuhan ekonomi, tetapi sebaliknya terdapat hubungan negatif antara pertumbuhan ekonomi dengan cadangan sumberdaya alam yang ada di dalam bumi. Peningkatan pertumbuhan ekonomi suatu daerah biasanya diikuti dengan penurunan kualitas kondisi ekologisnya. Hal ini terlihat dari kondisi ekologi dan ekonomi DAS Cidanau dan DAS Baturusa. Tidak seperti karakteristik ekologi DAS Cidanau yang lebih baik dibandingkan DAS Baturusa, sebaliknya karakteristik ekonomi di DAS Baturusa menunjukkan keadaan yang lebih baik dibandingkan DAS
Cidanau. Karakteristik ekonomi diukur melalui indikator tingkat pendapatan per kapita serta tingkat kesejahteraan.

\section{Tingkat Pendapatan Per Kapita}

Tingkat pendapatan masyarakat DAS Cidanau sangat berkaitan dengan mata pencaharian atau kegiatan yang dilakukan oleh masyarakat dalam kehidupan sehari-hari. Mata pencaharian utama masyarakat DAS Cidanau didominasi oleh sektor pertanian dan selainnya adalah pedagang, PNS, pertukangan dan lain-lain. Kegiatan pertanian yang merupakan mata pencaharian utama yang ada di wilayah hulu ini adalah meliputi padi, palawija, hortikultura, perkebunan rakyat, dan hutan rakyat. Sedangkan hewan ternak yang dikembangkan di wilayah hulu DAS Cidanau antara lain kerbau, kambing, domba dan unggas. Pendapatan ratarata per kapita dan per desa masyarakat hulu DAS Cidanau dapat dilihat pada Tabel 5.

Tingkat pendapatan per kapita rata-rata masyarakat di hulu DAS Cidanau mencapai Rp 625.250/bulan. Masyarakat DAS Cidanau seharusnya dapat memperoleh tingkat pendapatan yang lebih besar dari nilai tersebut, jika mekanisme insentif hulu-hilir yang berjalan sudah sesuai dengan hasil perhitungan nilai jasa lingkungan yang sesungguhnya. Hal ini didasarkan dengan asumsi bahwa wilayah hulu DAS Cidanau memiliki nilai manfaat yang jauh lebih besar dibandingan dengan mekanisme insentif yang telah diberlakukan saat ini. Namun demikian, hingga saat ini belum ada hasil penelitian yang terkait berapa seharusnya nilai manfaat hulu DAS Cidanau yang harus dibayar oleh para pengguna di hilir.

Tabel 5. Pendapatan rata-rata masyarakat hulu DAS Cidanau pada tahun 2009

Table 5. Avarage Income of Community at Upper Cidanau Watershed in 2009

\begin{tabular}{llcr}
\hline Kecamatan (Sub District) & $\begin{array}{c}\text { Kabupaten } \\
(\text { Regency) }\end{array}$ & $\begin{array}{c}\text { Pendapatan } \\
\text { rata-rata per kapita/th } \\
\text { (Average income } \\
\text { percapita/year) (Rp) }\end{array}$ & $\begin{array}{c}\text { Pendapatan rata-rata per } \\
\text { desa/th (Average income } \\
\text { village/year) (Rp) }\end{array}$ \\
\hline Ciomas & Serang & 11.212 .541 & 41.751 .766 .075 \\
Padarincang & Serang & 6.644 .570 & 31.585 .728 .681 \\
Mandalawangi & Pandeglang & 4.651 .968 & $13.078 .543,401$ \\
\hline
\end{tabular}

Sumber (Source): Data BPS diolah (BPS calc) 
Berdasarkan pendapatan perkapita, pada tiga kecamatan wilayah hulu DAS Cidanau tersebut masih berada di atas angka garis kemiskinan tingkat Provinsi Banten. Menurut BPS, garis kemiskinan atau kemiskinan secara absolut, adalah standar kehidupan minimum yang dibutuhkan untuk memenuhi kebutuhan dasar yang diperlukan baik makanan maupun non makanan. Garis kemiskinan ini adalah nilai rupiah yang harus dikeluarkan seseorang dalam sebulan agar dapat memenuhi kebutuhan dasar asupan kalori sebesar 2.100 $\mathrm{kkal} /$ hari per kapita (garis kemiskinan makanan) ditambah kebutuhan minimum non makanan yang merupakan kebutuhan dasar seseorang, yaitu papan, sandang, sekolah, transportasi serta kebutuhan individu dan rumah tangga dasar lainnya (garis kemiskinan non makanan). Berdasarkan hasil perhitungan BPS tahun 2009, garis kemiskinan Provinsi Banten adalah urutan ke-18 dari 33 provinsi yang ada di Indonesia yaitu Rp 198.750 /kapita/bulan.

Berdasarkan distribusinya, rata-rata pendapatan masyarakat di hulu DAS Cidanau yang dihitung dengan koefisien gini dengan persentase kumulatif penduduk dan total pendapatan yang diterima oleh masing-masing prosentase penduduk tersebut menunjukkan bahwa pendapatan masyarakat tersebut terdistribusi cukup merata atau tidak terjadi ketimpangan pendapatan yang berarti. Hal ini ditunjukkan dengan nilai koefisien gini sebesar 0,2 atau mendekati 0 yang berarti distribusi pendapatan cukup merata. Koefisien gini adalah salah satu ukuran yang paling sering digunakan untuk mengukur tingkat ketimpangan pendapatan secara menyeluruh. Distribusi pendapatan ini merupakan salah satu aspek kemiskinan yang perlu diperhatikan karena pada dasarnya merupakan ukuran kemiskinan relatif, yaitu kemiskinan yang standar penilaiannya merupakan standar kehidupan yang ditentukan dan ditetapkan secara subyektif oleh masyarakat setempat dan bersifat lokal.

Berdasarkan Tabel 5, masyarakat Kecamatan Ciomas memiliki rata-rata pendapat lebih tinggi dibandingkan masyarakat Kecamatan Padarincang. Hal ini diperkirakan karena adanya tambahan insentif jasa lingkungan sebesar Rp 1,2 juta/ha/ tahun dengan luasan minimal 5 ha per kelompok yang sudah berjalan dengan baik dan telah memasuki periode kedua. Selain itu, kedua kecamatan ini memiliki struktur penggunaan lahan yang ber- beda dimana Kecamatan Ciomas sekitar 58\% lahan pertaniannya didominasi oleh tegalan atau kebun. Kebun ini umumnya ditanami antara lain jenis buah-buahan seperti durian, mangga, pisang, sawo, dan pepaya. Pisang dan durian merupakan komoditi unggulan dengan produksi rata-rata secara berturut-turut 1.360,60 ton dan 740,40 ton per ha/tahun. Sementara itu, di Kecamatan Padarincang karena populasi yang lebih padat, lahan kebun/tegalan hanya sekitar $15 \%$ dan lainnya didominasi oleh sawah (40\%) dengan komoditi pertanian padi dan palawija, dan perkebunan $(44,7 \%)$. Perkebunan di wilayah ini dibedakan atas Perkebunan Besar Negara, Perkebunan Besar Swasta dan Perkebunan Rakyat. Perkebunan Besar Swasta hanya terdapat satu perusahaan dengan luas hak guna usaha 506,57 ha untuk budidaya tanaman karet, sementara perkebunan rakyat meliputi areal yang cukup luas yaitu 30.602,50 ha dengan komoditi utama kelapa, kopi, cengkeh dan melinjo. Di Desa Citasuk Kecamatan Padarincang, komoditi unggulan utama dari perkebunan rakyat adalah kelapa dengan luas penanaman 1.584,68 ha dengan total produksi 70,45 ton/tahun. Sementara di Desa Kadubeureum komoditi unggulannya adalah kopi dengan luas penanaman 492,14 ha dan produksi rata-rata 0,25 ton/ ha dengan total produksi 237,65 ton/tahun. Masih dalam Kecamatan Padarincang, Desa Padarincang memiliki komoditi unggulaan cengkeh dengan produksi rata-rata 0,20 ton/ha dengan total produksi 80,15 ton/ha pada areal seluas 463,14 ha.

Distribusi sebaran rata-rata pendapatan desa DAS Cidanau dianalisis melalui GIS untuk mengetahui hubungan antara tingkat pendapatan desa dan tutupan lahan serta fungsi kawasan hutan yang ada di DAS Cidanau seperti yang terlihat pada Gambar 5.

Hasil analisis GIS mengindikasikan bahwa desa di DAS Cidanau dengan rata-rata pendapatan tinggi pada umumnya memiliki areal persawahan, pertanian lahan kering dan hutan tanaman yang luas. Adapun desa-desa yang didominasi oleh hutan sekunder, hutan tanaman dan pertanian lahan kering yang sempit memiliki rata-rata pendapatan yang rendah. Hal tersebut mengindikasikan bahwa lahan pertanian dan kebun/ hutan yang mereka miliki memberikan tambahan pendapatan yang cukup signifikan. 


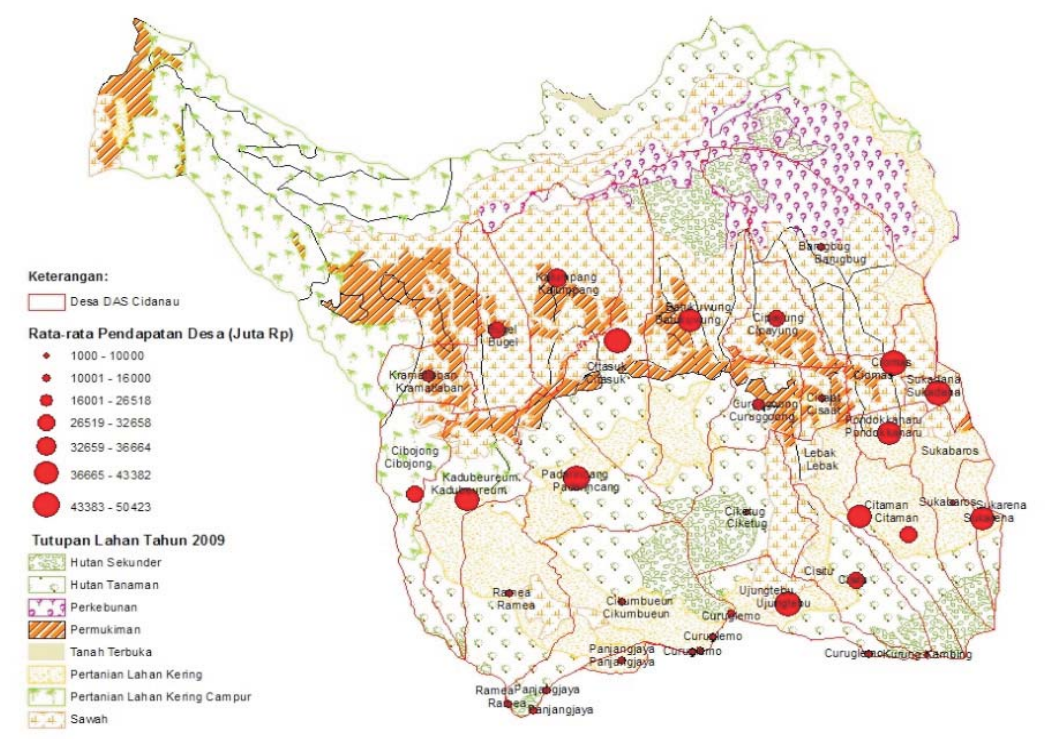

Gambar 5. Hubungan antara rata-rata pendapatan dengan tipe tutupan lahan di DAS Cidanau.

Figure 5. Corelation of Avarage Income with Types of Forest Cover at Cidanau Watershed.

Tabel 6. Pendapatan rata-rata masyarakat hulu DAS Baturusa pada tahun 2009

Table 6. Avarage Income of Community at Upper Baturusa Watershed in 2009

\begin{tabular}{lrr}
\hline \multicolumn{1}{c}{ Kecamatan (Sub District) } & $\begin{array}{l}\text { Pendapatan rata-rata per kapita/th } \\
\text { (Average income percapita/year) }(\mathrm{Rp})\end{array}$ & $\begin{array}{l}\text { Pendapatan rata-rata per desa/th } \\
\text { (Average income per village/year }(\mathrm{Rp})\end{array}$ \\
\hline Bakam & $43.299 .594,23$ & 84.183 .071 .100 \\
Merawang & $26.679 .478,53$ & 67.164 .105 .006 \\
\hline
\end{tabular}

Sumber (Source): Data BPS diolah (BPS calc)

Kondisi sebaliknya terjadi di DAS Baturusa. Dengan tutupan hutan hanya mencapai 3,18\%, tingkat pendapatan penduduk di hulu DAS Baturusa mencapai Rp 2.915.800/bulan. Angka ini jauh berada di atas garis kemiskinan Provinsi Bangka Belitung yang hanya Rp 266.843/kapita/ bulan. Masyarakat di DAS Baturusa pada umumnya memiliki pendapatan dari hasil kebun serta dari menambang timah. Komoditi perkebunan yang umum ditanam masyarakat DAS Baturusa adalah jenis tanaman perkebunan seperti lada, karet, coklat, kakao dan sawit.

Rata-rata luas kepemilikan lahan yang terkecil di DAS Baturusa ini adalah 2 ha per kepala keluarga. Namun tidak sedikit masyarakat yang memiliki puluhan bahkan belasan hektar lahan. Sementara itu penghasilan dari penambangan timah dapat mencapai Rp 2 sampai dengan 3 juta atau rata-rata sebesar Rp 2,5 juta per bulan (asumsi harga timah Rp 100.000/kg). Masyarakat pada umumnya melakukan penambangan pada pagi hari, sedangkan siang hingga sore hari aktivitas lebih banyak dilakukan di ladang kebun.
Berdasarkan tabel 6, masyarakat Kabupaten Bakam memiliki tingkat pendapatan yang lebih tinggi dibandingkan masyarakat Kabupaten Merawang. Hal ini dipengaruhi oleh arel perkebunan karet yang merupakan komoditi unggulan di Kabupaten Bakam lebih luas dibandingkan Kabupaten Merawang. Berdasarkan data BPS, luas perkebunan karet di Kabupaten Bakam mencapai 1.452 ha dengan produksi getah karet sebesar 1830,68 ton. Sedangkan luas perkebunan karet di Kabupaten Merawang hanya mencapai 217 ha dengan produksi sebesar 273,42 .

Sedangkan hubungan antara rata-rata pendapatan desa DAS Baturusa dengan kondisi tutupan lahan dan fungsi kawasan dianalisis dengan GIS dengan hasil seperti pada gambar 6 . Hasil analisis GIS menunjukkan bahwa desa dengan rata-rata pendapatan yang tinggi pada umumnya didominasi oleh tutupan lahan berupa pertanian lahan kering campur, pertanian lahan kering dan perkebunan dengan status fungsi lahan berupa areal penggunaan lain. 


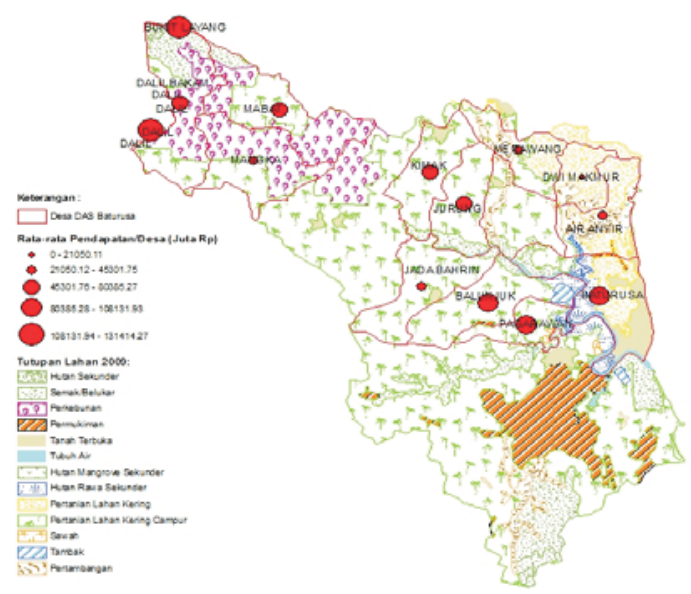

Gambar 6. Hubungan rata-rata pendapatan dengan tutupan lahan dan kawasan hutan di DAS Baturusa. Figure 6. Corelation of Avarage Income with Forest Cover at Baturusa Watershed.

\section{Tingkat Kesejahteraan}

Menurut Segel dan Bruzy (1998), kesejahteraan sosial adalah kondisi sejahtera dari suatu masyarakat yang meliputi kesehatan, keadaan ekonomi, kebahagiaan dan kualitas hidup rakyat. BPS menggolongkan indikator kesejahteraan menjadi 2, yaitu indikator tunggal dan indikator komposit/ jamak. Indikator tunggal meliputi pendidikan, kesehatan, ekonomi, angkatan kerja, perumahan, dan sanitasi. Sedangkan indikator jamak meliputi indeks pembangunan manusia, indeks kemiskinan manusia dan indeks mutu hidup. Indikator perumahan meliputi persentase kepemilikan rumah, persentase rumah berkualitas baik, serta persentase rumah tangga mempunyai sumber penerangan listrik.

Karena lokasi penelitian berada pada wilayah pedesaan di hulu DAS Cidanau dan DAS Baturusa maka tingkat kesejahteraan pada penelitian ini diukur melalui indikator tunggal perumahan dengan melihat secara langsung kondisi perumahan rata-rata penduduk yang berada di wilayah hulu DAS. Pada umumnya kondisi rumah masyarakat yang berada di hulu DAS Baturusa lebih baik dibandingkan masyarakat di DAS Cidanau. Kondisi rumah masyarakat di DAS Baturusa pada umumya bersifat permanen, berlantai keramik dan beratap genteng atau asbes. Sedangkan kondisi rumah masyarakat di DAS Cidanau pada umumnya bersifat semi permanen, dengan lantai semen dan atap genteng. Kondisi tersebut menunjukkan bahwa tingkat kesejahteraan masyarakat di hulu DAS Baturusa lebih baik dibandingkan masyarakat di hulu DAS Cidanau.
Jika dihubungkan dengan tingkat pendapatan, maka pada masyarakat DAS Baturusa yang memiliki tingkat pendapatan lebih tinggi dibandingkan masyarakat DAS Cidanau dapat dikatakan bahwa tingkat pendapatan yang tinggi akan meningkatkan tingkat kesejahteraan. Hal ini disebabkan masyarakat dengan pendapatan yang lebih tinggi dapat menggunakan uangnya untuk membangun rumah yang sehat dan nyaman. Sementara untuk masyarakat dengan tingkat pendapatan rendah, mereka tidak mampu membiayai pembangunan rumah yang sehat dan nyaman.

Dengan demikian, perbedaan karakteristik ekologi, sosial dan ekonomi DAS Cidanau dan Baturusa dapat dilihat seperti pada Tabel 7 . Berdasarkan Tabel 7, DAS Cidanau memiliki kondisi ekologis yang relatif lebih baik dibandingkan DAS Baturusa. Hal tersebut dapat dilihat berdasarkan tutupan hutan yang lebih luas, debit air yang lebih tinggi dan kualitas air yang relatif lebih baik. Sebaliknya, kondisi ekonomi masyarakat di wilayah DAS Baturusa lebih baik dibandingkan DAS Cidanau yang ditunjukkan dengan rata-rata tingkat pendapatan yang lima kali lebih besar dan kondisi tempat tinggal yang lebih baik. Namun demikian, tingkat pendapatan yang jauh lebih tinggi pada masyarakat DAS Baturusa, pada hakikatnya belum mencerminkan tingkat kesejahteraan yang sesungguhnya bagi masyarakat sekitar DAS tersebut Hal tersebut disebabkan tingginya pendapatan masyarakat tersebut bersumber dari hasil timah yang seiring dengan waktu produksinya akan berkurang. Di sisi lain, 
akibat penambangan tersebut kondisi lahan akan semakin rusak yang mengakibatkan sumber makanan dan minuman sulit didapat karena kondisi lahan yang tidak subur dan kuantitas serta kualitas air minum yang semakin rendah. Kondisi tersebut dapat diartikan bahwa tanpa sumber daya alam tambang, tingkat kesejahteraan masyarakat DAS Baturusa tidak lebih baik dibandingkan dengan tingkat kesejahteraan masyarakat DAS Cidanau. Kondisi tersebut dapat dilihat dari keadaan sosial dimana tingkat pendidikan masyarakat pada kedua DAS ini yang relatif sama. Padahal seharusnya dengan pendapatan yang jauh lebih tinggi, tingkat pendidikan masyarakat DAS Cibarusa jauh lebih baik. Dengan demikian, mengingat timah merupakan jenis sumber daya alam yang tidak dapat diperbaharui maka diperlukan alternatif sumber penghasilan lain untuk keberlangsungan kehidupan masyarakat DAS Cidanau Baturusa pada masa yang akan datang.

Tabel 7. Karakteristik ekologi, ekonomi dan sosial DAS Cidanau dan DAS Baturusa pada tahun 2009

Table 7. Characteristics of ecology, economy, and social at Cidanau and Baturusa watershed in 2009

\begin{tabular}{|c|c|c|}
\hline $\begin{array}{c}\text { Karakteristik DAS } \\
\text { (Watershed Characteristics) }\end{array}$ & $\begin{array}{l}\text { DAS Cidanau } \\
\text { (Cidanau Watershed) }\end{array}$ & $\begin{array}{l}\text { DAS Baturusa } \\
\text { (Baturusa Watershed) }\end{array}$ \\
\hline A) Ekologi / Ecology & & \\
\hline a. Tutupan Lahan $(\mathrm{Ha})$ & $7.371,28(32,83 \%)$ & $2.165,83(3,18 \%)$ \\
\hline b. Debit Air $(\mathrm{m} 3 / \mathrm{s})^{* *}$ & 7,08 & 0,182 \\
\hline c. Tingkat Pencemaran air & Kualitas baik & Ringan - Sedang \\
\hline \multicolumn{3}{|l|}{ B) Sosial / Social } \\
\hline $\begin{array}{l}\text { a. Kepadatan Penduduk* } \\
\text { (jiwa } / \mathrm{km} 2 \text { ) }\end{array}$ & 812,5 & 107,5 \\
\hline \multicolumn{3}{|l|}{ b. Tingkat Pendidikan* } \\
\hline - SD (jiwa) & $5.393(79,94 \%)$ & $2075(78,30 \%)$ \\
\hline - SMP (jiwa) & $1.043(15,46 \%)$ & $373(14,07 \%)$ \\
\hline - SMA (jiwa) & $310(4,59 \%)$ & $202(7,62 \%)$ \\
\hline \multicolumn{3}{|l|}{ C) Ekonomi / Economy* } \\
\hline \multirow{4}{*}{$\begin{array}{l}\text { a. Tingkat Pendapatan/ } \\
\text { Perkapita (Rp/ bln) } \\
\text { b. Tingkat Kesejahteraan } \\
\end{array}$} & 625.250 & 2.915 .800 \\
\hline & Kondisi lantai rumah semen & Kondisi lantai rumah keramik \\
\hline & $\begin{array}{l}\text { Kondisi dinding umumnya semi } \\
\text { permanen }\end{array}$ & Kondisi dinding umumnya permanen \\
\hline & Kondisi atap rumah genteng & Kondisi atap rumah genteng atau asbes \\
\hline
\end{tabular}

\section{KESIMPULAN DAN SARAN}

\section{A. Kesimpulan}

Selain indikator tingkat pendidikan yang relatif sama, antara DAS Ciliwung dan DAS Baturusa memiliki parameter karakteristik yang jauh berbeda baik pada aspek ekologi (tutupan lahan, debit air, dan tingkat pencemaran), sosial (kepadatan penduduk) maupun ekonomi (tingkat kesejahteraan dan pendapatan). Perbedaan karakteristik tersebut selain disebabkan oleh faktor alam juga disebabkan oleh adanya stimulus ekonomi yang menjadi daya tarik bagi masyarakat dan sekaligus menentukan kondisi wilayah kedepannya.

Pada DAS Cidanau stimulus ekonomi bersumber dari mekanisme jasa lingkungan yang membawa ke arah perbaikan kondisi lanskap hutan yang dikoordinir oleh FKDC sehingga tutupan lahannya mencapai 32,83\%. Mekanisme jasa lingkungan ini sebaiknya dikelola dengan proporsi pembayaran yang sesuai dengan nilai riil lingkungan sesungguhnya.

Pada DAS Baturusa stimulus ekonomi bersumber dari sektor pertambangan baik legal dan illegal yang justru membuat kondisi lanskap hutan 
menjadi semakin rusak. Kondisi tersebut menuntut perhatian untuk segera dilakukan perbaikan antara lain yaitu melalui penegakan hukum yang mengatur lokasi-lokasi tertentu yang boleh dijadikan areal penambangan dan lokasi yang lain sebagai daerah konservasi yang harus direhabilitasi dan dijaga kelestariannya.

Secara umum tingkat kesejahteraan masyarakat di DAS Cidanau lebih baik dibandingkan dengan kehidupan masyarakat di DAS Baturusa terutama berkaitan dengan pendapatan dari kegiatan usaha berbasis lahan karena $86 \%$ pendapatan masyarakat di DAS Baturusa berasal dari hasil kerja di pertambangan timah.

Kegiatan sosialisasi, komunikasi, dan pembinaan tentang pentingnya fungsi hutan kepada masyarakat berpengaruh secara signifikan dalam meningkatkan kesadaran masyarakat terhadap kelestarian hutan yang pada gilirannya dapat mempengaruhi kelestarian pengelolaan lanskap hutan dalam suatu wilayah DAS.

\section{B.Saran}

Untuk mewujudkan upaya pengelolaan lanskap hutan secara lestari perlu memperhatikan karakteristik lanskap hutan sebagai dasar pengambilan kebijakan. Idealnya, pengelolaan lanskap hutan harus memberikan dampak positif terhadap karakteristik ekologi, ekonomi dan sosial.

Salah satu mekanisme yang dapat memberikan dampak positif terhadap karakteristik ekologi, ekonomi dan sosial lanskap hutan adalah mekanisme jasa lingkungan hulu hilir.

Perlu dilakukan suatu kajian ilmiah untuk menghitung besaran insentif dalam mekanisme hulu-hilir di DAS Cidanau sehingga diperoleh besaran yang ideal berdasarkan nilai jasa lingkungan yang sebenarnya dan dapat meningkatkan kesejahteraan masyarakat hulu DAS secara signifikan.

\section{DAFTAR PUSTAKA}

Asdak, C. (2010). Hidrologi dan pengelolaan daerah aliran sungai. Gajah Mada University Press.

Badan Pusat Statistik Kabupaten Bakam. (2010). Bakam Dalam Angka. Banten: Badan Pusat Statistik Kabupaten Bakam.
Badan Pusat Statistik Provinsi Banten. (2010). Banten dalam angka. Banten: Badan Pusat Statistik Provinsi Banten.

Badan Perencanaan Pembangunan Daerah, Provinsi Banten. (2008). Laporan final penyusunan rencana strategis pengelolaan DAS Cidanau. Banten: Badan Perencanaan Pembangunan Daerah, Provinsi Banten.

Badan Pusat Statistik Kabupaten Serang. (2010). Padarincang dalam angka. Banten: Badan Pusat Statistik Kabupaten Serang.

Badan Pusat Statistik Kabupaten Pandeglang. (2010). Mandalawangi dalam angka. Banten: Badan Pusat Statistik Kabupaten Pandeglang.

Badan Pusat Statistik Kabupaten Merawang. (2010). Merawang dalam angka. Banten: Badan Pusat Statistik Kabupaten Merawang.

Balai Pengelolaan DAS Baturusa Cerucuk. (2010). Statistik Balai Pengelolaan DAS Baturusa Cerucuk. Pangkal Pinang: Balai Pengelolaan DAS Baturusa Cerucuk.

Bennet, J.W. (1976). The ecological transition : cultural anthropology and human adaptation. New York. Pergamon Press.

Burroughhs, R. (1999). When stakeholders choose: Process, knowledge, and motivation in water quality decisions. Society and Natural Resources 53(12), 797-809.

Badan Pusat Statistik Kabupaten Serang. (2010). Ciomas dalam angka. Banten: Badan Pusat Statistik Kabupaten Serang.

Forman, R.T.T. \& Godron, M. (1986). Landscape ecology. New York. USA: John Wiley and Sons.

Hefni, E. (2003). Telaah kualitas air bagi pengelolaan sumber daya dan lingkungan perairan. Jakarta: Kanisius.

Jennings, S., R. Nussbaum, Judd N., \& Synnott, T. (2002). Identifying high conservation values at a national level. Oxford, UK: ProForest.

Lubchenco, J., Olson, A.M., Bruber, S.R., Carpenter, M.M., Holland, S.P., Hubbell, S.A., Real, P.J. (2009). The sustainable 
biosphere initiative : an ecological research agenda. Ecology 72, 371 - 412.

Maryani R. dan F. Nurfatriani. (2010). Review status riset manajemen lanskap hutan. Laporan Hasil Penelitian. Bogor: Puslitbang Perubahan Iklim dan Kebijakan.

Naiman R. J. (1992). Watershed management. balancing sustainability and environmental Change. Springer.

Naiman, R.J. \& Decamps, H. (1990). The ecology and management of aquatic terrestrial ecotones. Carnforth, United Kingdom. UNESCO. Paris, and Parthenon Publishing Group.

Napier, T.L. \& Forster, D.L. (1982). Farmer attitudes and behaviour associated with soil erosion control. Pp. 137-150.

Paimin, Sukresno \& Purwanto, (2010). Sidik cepat degradasi sub daerah aliran sungai. Bogor: Pusat Penelitian dan Pengembangan Konservasi dan Rehabilitasi.

Peraturan Pemerintah Nomor 82 tahun 2001 tentang Pengelolaan Kualitas Air dan Pengendalian Pencemaran.
Purwanto, Pramono, I.B., \& Indrawati, D.R. (2002). Monitoring dan evalusi pengelolaan DAS. Diunduh dari http:// bebasbanjir2025. wordpress. com. (25 Maret 2011).

Rhoads, B., Wilson, D., Urban, M., \& Herricks, E., (1999). Interaction between scientists and nonscientist in community-based watershed management; emergence of the concept of stream naturalization. Environmental Management 24, 297-308.

Suparmoko. (2008). Ekonomi sumberdaya alam dan lingkungan. Yogyakarta: BPFE.

Turner, M.G. (1989). Landscape ecology : The effect of pattern on process. Annual Review of Ecology and Systematics 20:171 - 197.

Wagner, M.M. (2005). Watershed-scale social assessment. Journal of Soil and Water Conservation, 60, 4: Proquest Research Library page 177. 